\title{
Dosis Pupuk Npk Terhadap Pertumbuhan dan Hasil Jagung Hibrida
}

\author{
Pricillia Galuh Pusparini ${ }^{1}$, Ahmad Yunus ${ }^{2)^{*}}$, Dwi Harjoko ${ }^{2)}$
}

\begin{abstract}
Corn is an important crop. Potency of corn productivity in Indonesia are still low. Main obstacles of increasing corn productivity is convertion of fertile land into non agriculture interest. the increase of corn productivity can be done by administrating NPK fertilizer and hybrid variety. This research is aiming at deciding and analyzing the effect of NPK fertilizer administration and hybrid corn variety towards growth and result. This research was held in June to October 2017, at Srimartani Village, Piyungan Districts, Bantul Regency, Daerah Istimewa Yogyakarta with regosol soil type and land altitude around 80 meter above sea surface. This experiment arranged in split plot design by factorial. Experimented factor are two corn hybrid variety ABCD and EFGH (main plot) with three doses of NPK fertilizer 200, 300 and $400 \mathrm{~kg} \mathrm{ha}^{-1}$ (sub plot). The result of research show that there are responds in two variety towards NPK fertilizer dosage almost same (unreal interraction). ABCD and EFGH variety reach highest result of height and component at $300 \mathrm{~kg} \mathrm{ha}^{-1}$ doses. Variable of cob weight with husk, cob weight without husk, cob length, total row, dry pipilan weight per plot, 100 seeds weight, fresh stover wieght, dry stover weight, harvest index and yield per hectare the highest average is variety of EFGH. NPK fertilizer dosage $300 \mathrm{~kg} \mathrm{ha}^{-1}$ is the best amount to optimally increase the growth and yield of hybird corn $\left(8,92\right.$ ton ha $\left.{ }^{-1}\right)$. EFGH variety with $300 \mathrm{~kg} \mathrm{ha}^{-1} \mathrm{NPK}^{-1}$ fertilizer dosage can increase the potency of hybird corn yield. EFGH variety is showing better results $\left(9,26\right.$ ton ha $\left.{ }^{-1}\right)$.
\end{abstract}

Keywords: Zea mays, Productivity, Variety

\section{PENDAHULUAN}

Jagung (Zea mays L.) merupakan tanaman penting, karena kaya akan serat pangan yang dibutuhkan tubuh (Suarni dan Muh Yasin 2011). Selain untuk pangan dapat dimanfaatkan sebagai pakan dan industri lain. Potensi produktivitas jagung di Indonesia dapat mencapai 7,0-7,5 ton ha ${ }^{-1}$ tetapi masih jauh dari harapan karena, tahun 2010 tercatat produksi jagung hanya 4,43 ton ha ${ }^{-1}$ (BPS 2010). Kendala utama produksi jagung adalah konversi lahan subur untuk kepentingan nonpertanian (Adger 2005).

Penggunaan jagung hibrida dan pupuk NPK merupakan upaya untuk meningkatkan produksi. Jagung hibrida merupakan persilangan dua atau lebih induk unggul, merupakan generasi pertama hasil persilangan antara tetua (induk) berupa galur murni, galur harapan atau bersari bebas. Keunggulan memberikan peluang hasil lebih tinggi dibandingkan jagung komposit, namun kelemahan dari jagung hibrida biji hasil produksi tidak dapat digunakan sebagai sumber benih.

Tanaman memerlukan unsur hara terutama N, P, K saat fase vegetatif dan generatif. Unsur $\mathrm{N}$ berperan untuk pembentukan karbohidrat, protein, lemak dan persenyawaan organik lain dan unsur $\mathrm{P}$ berperan dalam pembentukan bagian generatif tanaman (Mulyani 2008). Unsur $\mathrm{K}$ berperan dalam memacu translokasi karbohidrat dari daun ke organ tanaman.

"Mahasiswa Program Studi Agroteknologi Fakultas

Pertanian UNS, Surakarta

2) Staf Pengajar Program Studi Agroteknologi Fakultas

Pertanian UNS, Surakarta

Author Contact: yunus.uns7@gmail.com
Penggunaan pupuk anorganik untuk meningkatkan hasil telah terbukti efektif hanya dalam beberapa tahun, menurut penggunaan yang konsisten berdasarkan jangka panjang (Stephen et al. 2014). Pertumbuhan tanaman dapat optimal apablia unsur hara yang tercukupi. Penelitian ini bertujuan untuk menentukan dan mengkaji pengaruh pemberian pupuk NPK dan varietas jagung hibrida terhadap pertumbuhan dan hasil.

\section{BAHAN DAN METODE}

Penelitian dilaksanakan bulan Juni sampai Oktober 2017, di Desa Srimartani, Kecamatan Piyungan, Kabupaten Bantul, Daerah Istimewa Yogyakarta dengan jenis tanah regosol dan Laboraturium Ekologi dan Manajemen Produksi Tanaman Fakultas Pertanian (EMPT) UNS. Bahan yang digunakan meliputi benih jagung hibrida varietas $A B C D$ dan EFGH, pupuk urea serta pupuk NPK.

Penelitian dengan percobaan disusun dengan rancangan petak terpisah (Split Plot Design), terdiri dari 2 faktor yaitu varietas (ABCD dan EFGH) dan dosis pupuk NPK (15: 15: 15) (200, 300 dan 400 kg/ha). Setiap perlakuan diulang sebanyak 3 kali, sehingga diperoleh 18 unit percobaan. Data hasil penelitian yang diperoleh dianalisis ragam taraf $5 \%$ uji lanjut Duncan's Multiple Range Test (DMRT) dengan tingkat kepercayaan $5 \%$.

\section{HASIL DAN PEMBAHASAN}

\section{Tinggi tanaman}

Tinggi tanaman untuk mengetahui pertumbuhan tanaman pada fase vegetatif akibat perlakuan. Hasil analisis ragam menunjukkan bahwa varietas memiliki 
perbedaan tinggi tanaman saat 10 minggu setelah tanam (MST) (Gambar 1). Dosis pupuk NPK tidak meningkatkan tinggi tanaman 10 MST (Gambar 2).

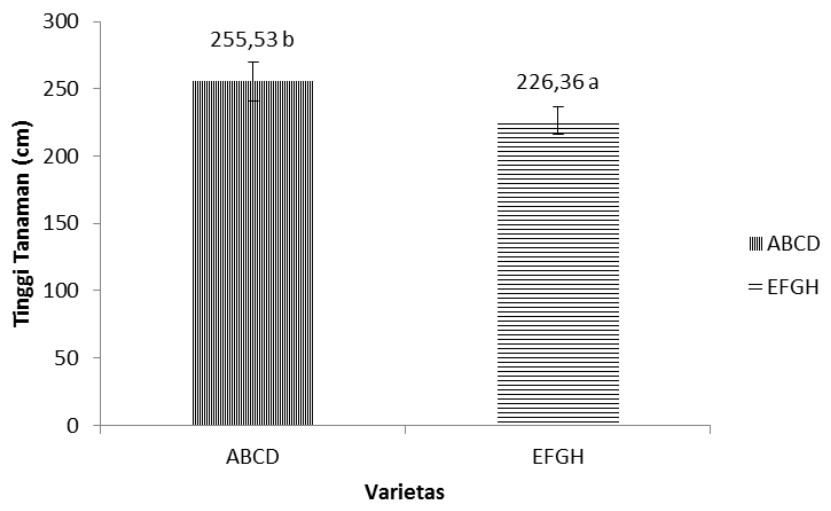

Gambar 1 Tinggi jagung umur 10 MST pada dua varietas

Gambar 1 menunjukkan bahwa ABCD lebih tinggi dibandingkan EFGH. Interaksi antara varietas dan dosis pupuk NPK tidak nyata. Tinggi tanaman saat 10 MST varietas $A B C D$ mencapai $255,53 \mathrm{~cm}$, sedangkan varietas EFGH mencapai 226,36 cm (Gambar 1). Berdasarkan deskripsi varietas menurut Advanta Seed Indonesia (2014), EFGH memiliki tinggi $\pm 196 \mathrm{~cm}$, sedangkan ABCD $\pm 208 \mathrm{~cm}$. Selisih antara kedua varietas adalah 29,17 cm. Tinggi jagung yang beragam karena, kedua varietas ini masih dalam pengembangan dan memiliki faktor genetik yang berbeda. Gardner (1991) menyatakan bahwa, varietas berpengaruh terhadap variabel pengamatan disebabkan perbedaan faktor genetik dan kemampuan adaptasi terhadap lingkungan. Tinggi jagung umur 10 MST pada dosis pupuk NPK disajikan dalam Gambar 2.

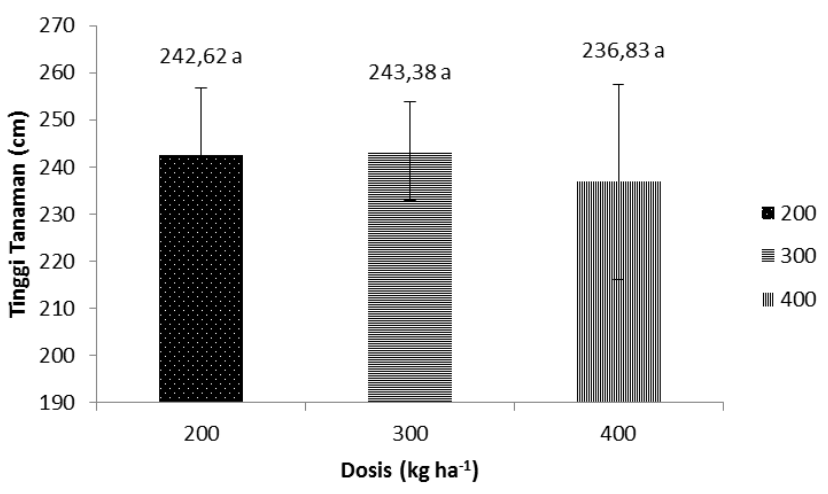

Gambar 2 Tinggi jagung umur 10 MST pada dosis pupuk NPK

Dosis pupuk NPK pada gambar 2 menunjukkan bahwa tidak meningkatkan tinggi tanaman saat 10 (MST). Tinggi tanaman pada dosis $300 \mathrm{~kg} \mathrm{ha}^{-1}$ lebih tinggi dibandingkan dosis lain yang mencapai 243,38 $\mathrm{cm}$ (Gambar 2). Pada dosis $200 \mathrm{~kg} \mathrm{ha}^{-1}$ tinggi tanaman mencapai 242,62 cm dan $400 \mathrm{~kg} \mathrm{ha}^{-1}$ mencapai 236,83 $\mathrm{cm}$ (Gambar 2). Menurut penelitian Kasno dan Tia (2013), penambahan dosis menjadi $400 \mathrm{~kg} \mathrm{ha}^{-1}$ tidak meningkatkan tinggi tanaman. Penelitian Juandi dan
Selvie (2016), dosis pupuk NPK 200, 300, 400 dan 500 $\mathrm{kg} \mathrm{ha}^{-1}$ tidak meningkatkan tinggi tanaman, hal ini mungkin pertumbuhan jagung membutuhkan pasokan pupuk yang cukup sampai fase tasseling. Tidak adanya perbedaan tinggi tanaman akibat dosis pupuk NPK yang berbeda, diduga disebabkan kandungan hara pada petak percobaan masih relatif cukup tinggi untuk mendorong pertumbuhan tanaman. $\mathrm{N}$ merupakan komponen yang dikaitkan dengan aktivitas fotosintesis yang tinggi, pertumbuhan vegetatif yang kuat dan warna hijau tua pada daun (Ademiluyi 2015).

\section{Tasseling dan silking}

Pengamatan tasseling dan silking dilakukan untuk mengetahui pertumbuhan jagung hibrida saat fase generatif, umur muncul bunga ditetapkan apabila $75 \%$ tanaman dalam suatu penelitian telah mengeluarkan bunga jantan (tassel) dan pengamatan dinyatakan dalam hitungan hari. Rata-rata tasseling dan silking perlakuan varietas terdapat pada (tabel 2).

Tabel 2 Tasseling dan silking jagung hibrida pada perlakuan dua varietas

\begin{tabular}{lll}
\hline \multirow{2}{*}{ Variabel } & \multicolumn{2}{c}{ Varietas } \\
\cline { 2 - 3 } & $\mathrm{ABCD}$ & $\mathrm{EFGH}$ \\
\hline Tasseling (HST) & $52,49^{\mathrm{a}}$ & $55,33^{\mathrm{b}}$ \\
Silking (HST) & $56,96^{\mathrm{a}}$ & $59,12^{\mathrm{b}}$ \\
\hline
\end{tabular}

Keterangan : Angka yang diikuti huruf sama pada baris menunjukkan tidak beda nyata

Data pada tabel 2 menunjukkan bahwa kedua varietas memiliki tasseling dan silking berbeda, sedangkan dosis pupuk NPK tidak berpengaruh. Interaksi antara varietas dan dosis pupuk NPK tidak nyata. Varietas ABCD tassel muncul tercepat pada $52,49 \mathrm{HST}$, sedangkan varietas EFGH tassel muncul pada 55,33 HST (Tabel 2). Menurut penelitian Khairiyah et al (2017) varietas berpengaruh terhadap tasseling dan silking serta umur panen. Silking ABCD muncul tercepat pada 56.96 HST, dibandingkan EFGH yang muncul pada 59.12 HST (Tabel 2). Faktor lingkungan yang mempengaruhi adalah suhu dan panjang hari, dimana perbedaan suhu dan panjang hari akan memberikan pengaruh terhadap tanaman terhadap proses pemacuan kerja hormon yang berperan dalam pembentukan bunga dan menghambat kerja organ yang lain.

\section{Bobot tongkol dengan kelobot dan tanpa kelobot}

Pengamatan bobot tongkol dengan kelobot dan bobot tongkol tanpa kelobot dilakukan dengan menimbang tongkol dengan kelobot selanjutnya memisahkan antara kelobot dengan tongkol kemudian ditimbang. Variabel pengamatan ini menunjukkan hasil bahwa varietas tidak meningkatkan kedua variabel (Tabel 3). Dosis pupuk NPK meningkatkan kedua variabel (Tabel 4). Interaksi antara varietas dan dosis tidak nyata.

Varietas tidak meningkatkan bobot tongkol dengan kelobot. Varietas EFGH lebih tinggi daripada ABCD bobot tongkol dengan kelobot mencapai 363,96 gram 
(Tabel 3), sedangkan varietas ABCD mencapai 356,38 gram (Tabel 3), selisih antara kedua varietas variabel ini adalah 7,58 gram. Bobot tongkol tanpa kelobot pada EFGH mencapai 319,73 gram (Tabel 3), sedangkan ABCD mencapai 308,51 gram (Tabel 3), selisih antara kedua varietas variabel ini adalah 11,52 gram. Varietas $A B C D$ dan EFGH memiliki hasil beragam, hal ini dipengaruhi oleh faktor genetik. Menurut penelitian Syarifuddin (2012), kadar air dan dosis N mengakibatkan perbedaan nilai bobot tongkol dengan kelobot, bobot tongkol tanpa kelobot, serta panjang tongkol dan dapat juga dipengaruhi oleh faktor genetik. Bobot tongkol dengan kelobot dan tanpa kelobot pada dosis pupuk NPK disajikan dalam Tabel 4.

Tabel 3 Bobot tongkol dengan kelobot dan tanpa kelobot pada dua varietas jagung hibrida

\begin{tabular}{lll}
\hline \multirow{2}{*}{ Variabel } & \multicolumn{2}{c}{ Varietas } \\
\cline { 2 - 3 } & ABCD & EFGH \\
\hline $\begin{array}{l}\text { Bobot tongkol dengan } \\
\text { kelobot (gram) }\end{array}$ & $356,38^{\mathrm{a}}$ & $363,96^{\mathrm{a}}$ \\
$\begin{array}{l}\text { Bobot tongkol tanpa } \\
\text { kelobot (gram) }\end{array}$ & $308,51^{\mathrm{a}}$ & $319,73^{\mathrm{a}}$ \\
\hline
\end{tabular}

Keterangan: Angka yang diikuti huruf sama pada baris menunjukkan tidak beda nyata

Tabel 4 Bobot tongkol dengan kelobot dan tanpa kelobot jagung hibrida pada dosis pupuk NPK

\begin{tabular}{llll}
\hline \multirow{2}{*}{ Variabel } & \multicolumn{3}{c}{ Dosis Pupuk NPK $\left(\mathrm{kg} \mathrm{ha}^{-1}\right)$} \\
\cline { 2 - 4 } & 200 & 300 & 400 \\
\hline $\begin{array}{l}\text { Bobot tongkol } \\
\text { dengan kelobot }\end{array}$ & $326,92^{\mathrm{a}}$ & $400,78^{\mathrm{b}}$ & $352,80^{\mathrm{a}}$ \\
$\begin{array}{l}\text { (gram) } \\
\begin{array}{l}\text { Bobot tongkol } \\
\text { tanpa kelobot } \\
\text { (gram) }\end{array}\end{array}$ & $279,72^{\mathrm{a}}$ & $362,00^{\mathrm{b}}$ & $300,65^{\mathrm{a}}$ \\
\hline
\end{tabular}

Keterangan: Angka yang diikuti huruf sama pada baris menunjukkan tidak beda nyata berdasarkan uji DMRT taraf $5 \%$

Tabel 4 menunjukkan bahwa, dosis NPK $300 \mathrm{~kg}$ ha $^{-1}$ memiliki hasil lebih tinggi pada variabel bobot tongkol dengan kelobot yang mencapai 400,78 gram (Tabel 4), sedangkan dosis $200 \mathrm{~kg} \mathrm{ha}^{-1}$ hanya mencapai 326,92 gram (Tabel 4). Variabel bobot tongkol tanpa kelobot dosis NPK $300 \mathrm{~kg} \mathrm{ha}^{-1}$ juga lebih tinggi mencapai 362,00 gram (Tabel 4), sedangkan dosis NPK $200 \mathrm{~kg} \mathrm{ha}^{-1}$ hanya mencapai 279,72 gram (Tabel 4). Penelitian Ramanta (2008), pupuk anorganik meningkatkan bobot tongkol tanpa kelobot. Subekti (2008) menambahkan bahwa, pemberian dosis pupuk yang tepat perlu dilakukan untuk menyeimbangkan hara sehingga tanaman dapat tumbuh dan berkembang dengan baik.

\section{Jumlah baris dan panjang tongkol}

Varietas dapat meningkatkan jumlah baris per tongkol dan panjang tongkol, tetapi interaksi antara kedua variabel tidak nyata. Dosis pupuk NPK menunjukkan bahwa meningkatkan variabel jumlah baris, sedangkan pada panjang tongkol tidak meningkatkan. Hasil pengamatan jumlah baris per tongkol, panjang tongkol disajikan pada Tabel 5 dan Tabel 6.

Tabel 5 Jumlah baris per tongkol dan panjang tongkol pada dua varietas jagung hibrida

\begin{tabular}{lll}
\hline \multirow{2}{*}{ Variabel } & \multicolumn{2}{c}{ Varietas } \\
\cline { 2 - 3 } & ABCD & EFGH \\
\hline Jumlah baris per tongkol & $13,67^{\mathrm{a}}$ & $16,43^{\mathrm{b}}$ \\
(baris) & $20,48^{\mathrm{a}}$ & $24,87^{\mathrm{b}}$ \\
\hline
\end{tabular}

Keterangan: Angka yang diikuti huruf sama pada baris menunjukkan tidak beda nyata

Produktivitas jagung dapat ditentukan dari menghitung jumlah baris pertongkol, panjang tongkol dan bobot biji. Menurut Noviana (2011), varietas dengan tongkol yang lebih panjang berpeluang dalam memberikan hasil yang lebih tinggi. Karakter panjang tongkol menunjukkan kepadatan biji dan erat kaitannya dengan jumlah biji per tongkol. Tabel 5 menunjukkan bahwa varietas EFGH memiliki hasil lebih tinggi pada jumlah baris per tongkol mencapai 16,43 baris dibandingkan dengan varietas $A B C D$ yang mencapai 13,67 baris (Tabel 5), selisih antara kedua varietas variabel ini adalah 2,76 baris. Variabel panjang tongkol juga menunjukkan hasil bahwa varietas EFGH lebih tinggi yaitu mencapai $24,87 \mathrm{~cm}$ dibandingkan dengan varietas $A B C D$ yang mencapai $20,48 \mathrm{~cm}$ (Tabel 5), selisih antara kedua varietas variabel ini adalah 4,39 $\mathrm{cm}$. Jumlah baris per tongkol, panjang tongkol pada dosis pupuk NPK disajikan dalam Tabel 6.

Tabel 6 Jumlah baris per tongkol, panjang tongkol pada dosis pupuk NPK

\begin{tabular}{llll}
\hline \multirow{2}{*}{ Variabel } & \multicolumn{3}{c}{ Dosis Pupuk NPK $\left(\mathrm{kg} \mathrm{ha}^{-1}\right)$} \\
\cline { 2 - 4 } & 200 & 300 & 400 \\
\hline $\begin{array}{l}\text { Jumlah baris per } \\
\text { tongkol (baris) }\end{array}$ & $14,43^{\mathrm{a}}$ & $15,90^{\mathrm{b}}$ & $14,82^{\mathrm{a}}$ \\
$\begin{array}{l}\text { Panjang tongkol } \\
\text { (cm) }\end{array}$ & $22,20^{\mathrm{a}}$ & $23,05^{\mathrm{a}}$ & $22,77^{\mathrm{a}}$ \\
\hline
\end{tabular}

Keterangan: Angka yang diikuti huruf sama pada baris menunjukkan tidak beda nyata berdasarkan uji DMRT taraf $5 \%$

Tabel 6 menunjukkan bahwa dosis meningkatkan hasil pada jumlah baris per tongkol, sedangkan variabel panjang tongkol tidak meningkatkan hasil. Dosis 300 $\mathrm{kg} / \mathrm{ha}$ memberikan hasil lebih tinggi pada variabel jumlah baris per tongkol mencapai 15,90 baris (Tabel 6) dan 23,05 cm untuk panjang tongkol (Tabel 6). Dosis $300 \mathrm{~kg} \mathrm{ha}^{-1}$ dapat meningkatkan hasil dari tanaman, Suratmini (2009) menambahkan bahwa, pupuk NPK yang kurang dari $300 \mathrm{~kg} \mathrm{ha}^{-1}$ memiliki hasil yang rendah jika dibandingkan dengan dosis $300 \mathrm{~kg} \mathrm{ha}^{-1}$. Menurut Dosis $200 \mathrm{~kg} \mathrm{ha}^{-1}$ variabel jumlah baris mencapai 14,43 baris (Tabel 6) dan panjang tongkol mencapai 22,20 cm (Tabel 6). Interaksi antara kedua perlakuan tidak nyata. Menurut penelitian Sathish et al (2011) pemupukan NPK di stasiun penelitian Kathalagere meningkatkan hasil jagung dan serapan hara $\mathrm{N}, \mathrm{P}, \mathrm{K}$. 


\section{Bobot biji pipilan kering dan bobot 100 butir biji}

Bobot biji pipilan kering per plot dan bobot 100 butir biji merupakan variabel pengamatan dalam penelitian ini yang dilakukan setelah menimbang bobot tongkol dengan kelobot dan bobot tongkol tanpa kelobot. Varietas dapat meningkatkan bobot biji pipilan kering dan bobot 100 butir biji (Tabel 7). Dosis pupuk NPK tidak dapat meningkatkan terhadap kedua variabel (Tabel 8). Interaksi antara kedua variabel tidak nyata.

Tabel 7 Bobot pipilan kering per plot dan bobot 100 butir biji jagung pada dua varietas jagung hibrida

\begin{tabular}{lll}
\hline \multirow{2}{*}{ Variabel } & \multicolumn{2}{c}{ Varietas } \\
\cline { 2 - 3 } & ABCD & EFGH \\
\hline Bobot pipilan kering per & $6,59^{\mathrm{a}}$ & $7,49^{\mathrm{b}}$ \\
plot (kg) & $36,99^{\mathrm{b}}$ \\
\hline Bobot 100 butir biji (gram) & $31,90^{\mathrm{a}}$ & 36
\end{tabular}

Keterangan: Angka yang diikuti huruf sama pada baris menunjukkan tidak beda nyata

Bobot pipilan kering berkaitan dengan besarnya translokasi fotosintat ke dalam biji. Menurut Rahni (2012) bahwa, peningkatan bobot kering biji berkaitan dengan besarnya translokasi fotosintat ke dalam biji dan semakin baiknya sistem perakaran tanaman untuk dapat mengabsorbsi unsur hara dari dalam tanah. Translokasi fotosintat yang cukup besar ke organ reproduktif menyebabkan pembentukan tongkol dan pengisian biji berlangsung dengan baik dan biji yang terbentuk dengan ukuran yang lebih besar. Variabel bobot 100 butir biji menunjukkan bahwa varietas EFGH juga hasil lebih tinggi mencapai $36,99 \mathrm{~kg}$ (Tabel 7), sedangkan varietas $A B C D$ mencapai $31,90 \mathrm{~kg}$ (Tabel 7). Bobot pipilan kering per plot dan bobot 100 butir biji pada dosis pupuk NPK disajikan dalam Tabel 8.

Tabel 8 Bobot pipilan kering per plot dan bobot 100 butir biji jagung pada dosis pupuk NPK

\begin{tabular}{llll}
\hline \multirow{2}{*}{ Variabel } & \multicolumn{3}{c}{ Dosis Pupuk NPK $\left(\mathrm{kg} \mathrm{ha}^{-1}\right)$} \\
\cline { 2 - 4 } & 200 & 300 & 400 \\
\hline $\begin{array}{l}\text { Bobot pipilan kering } \\
\text { per plot (kg) }\end{array}$ & $6,73^{\mathrm{a}}$ & $7,22^{\mathrm{a}}$ & $7,18^{\mathrm{a}}$ \\
$\begin{array}{l}\text { Bobot 100 butir biji } \\
\text { (gram) }\end{array}$ & $32,95^{\mathrm{a}}$ & $35,85^{\mathrm{a}}$ & $34,53^{\mathrm{a}}$ \\
\hline
\end{tabular}

Keterangan: Angka yang diikuti huruf sama pada baris menunjukkan tidak beda nyata berdasarkan uji DMRT taraf $5 \%$

Dosis pupuk NPK berdasarkan tabel 10 tidak dapat meningkatkan bobot pipilan kering per plot dan bobot 100 butir biji. Dosis pupuk $300 \mathrm{~kg} \mathrm{ha}^{-1}$ hasil lebih tinggi pada variabel bobot pipilan kering per plot mencapai $7,22 \mathrm{~kg}$ (Tabel 8), sedangkan dosis $200 \mathrm{~kg} \mathrm{ha}^{-1}$ mencapai $6,73 \mathrm{~kg}$ (Tabel 8). Variabel bobot 100 butir biji menunjukkan hasil bahwa dosis $300 \mathrm{~kg} \mathrm{ha}^{-1}$ juga lebih tinggi mencapai $35,85 \mathrm{~kg}$ (Tabel 8 ), sedangkan dosis $200 \mathrm{~kg} \mathrm{ha}^{-1}$ mencapai $32,95 \mathrm{~kg}$ (Tabel 8). Hasilnya sesuai dengan penelitian dari Maqsood et al (2001), Mahmood et al (2001) dan Sharer et al (2003) bahwa, jumlah biji pertongkol meningkat pada dosis pupuk tertentu.

\section{Bobot segar brangkasan dan bobot kering brangkasan}

Pengamatan bobot segar brangkasan dilakukan pada akhir penelitian dengan cara menimbang seluruh bagian hijauan jagung sedangkan bobot kering brangkasan dilakukan setelah bagian hijauan dioven. Varietas dan dosis pupuk NPK dapat meningkatkan bobot segar dan bobot kering. Interaksi antara varietas dan dosis pupuk NPK tidak nyata (Tabel 9 dan 10).

Tabel 9 Bobot segar, bobot kering dan indeks panen jagung hibrida pada perlakuan dua varietas

\begin{tabular}{llll}
\hline Varietas & $\begin{array}{l}\text { Segar } \\
\text { (gram) }\end{array}$ & $\begin{array}{l}\text { Kering } \\
\text { (gram) }\end{array}$ & $\begin{array}{l}\text { Indeks } \\
\text { Panen }\end{array}$ \\
\hline ABCD & $364,62^{\mathrm{a}}$ & $207,79^{\mathrm{a}}$ & $0,39 \mathrm{a}$ \\
EFGH & $414,13^{\mathrm{b}}$ & $244,10^{\mathrm{b}}$ & $0,38 \mathrm{a}$ \\
\hline
\end{tabular}

Keterangan: Angka yang diikuti huruf sama pada baris menunjukkan tidak beda nyata

Tabel 9 menunjukkan bahwa, varietas meningkatkan bobot segar dan kering brangkasan. Varietas EFGH bobot kering brangkasan lebih tinggi mencapai 244,10 gram dan bobot segar brangkasan 414,13 gram (Tabel 9), sedangkan varietas ABCD bobot segar brangkasan mencapai 364,68 gram dan bobot kering brangkasan 207,79 gram (Tabel 9). Varietas dapat meningkatkan bobot segar dan kering karena terdapat perbedaan karakter genetik antara kedua varietas. Yulisma (2011) menambahkan bahwa, tinggi rendahnya nilai bobot segar brangkasan dan bobot kering brangkasan ditentukan oleh laju fotosintesis yang merupakan penimbunan fotosintat selama pertumbuhan. Indeks panen penelitian ini berkisar 0,370,39 (Tabel 9). Menurut Goldsworthy dan Fisher (1992), indeks panen optimal dapat bervariasi antara 0,15-0,52 dimana dipengaruhi oleh lama dan laju pertumbuhan. Bobot segar, bobot kering dan indeks panen pada dosis pupuk NPK disajikan dalam Tabel 10.

Tabel 10 menunjukkan bahwa dosis dapat meningkatkan bobot segar brangkasan dan bobot kering brangkasan. Dosis $300 \mathrm{~kg} \mathrm{ha}^{-1}$ memiliki hasil lebih tinggi untuk bobot segar brangkasan mencapai 422,00 gram dan bobot kering brangkasan mencapai 233,67 gram (Tabel 10). Dosis $200 \mathrm{~kg} \mathrm{ha}^{-1}$ bobot segar brangkasan 358,05 gram dan bobot kering brangkasan 212,05 gram (Tabel 10). Menurut Tubherkih dan Sipahutar (2008) pupuk NPK meningkatkan bobot kering brangkasan. Untuk mencapai keseimbangan hara, pemupukan NPK majemuk masih perlu ditambah pupuk tunggal, terutama sumber hara $\mathrm{N}$.

Tabel 10 Bobot segar, bobot kering dan indeks panen jagung hibrida pada dosis pupuk NPK

\begin{tabular}{llll}
\hline $\begin{array}{l}\text { Dosis Pupuk } \\
\text { NPK } \\
\left(\mathrm{kg} \mathrm{ha}^{-1}\right)\end{array}$ & $\begin{array}{l}\text { Segar } \\
(\mathrm{gram})\end{array}$ & $\begin{array}{l}\text { Kering } \\
(\text { gram })\end{array}$ & $\begin{array}{l}\text { Indeks } \\
\text { Panen }\end{array}$ \\
\hline 200 & $358,05^{\mathrm{a}}$ & $212,05^{\mathrm{a}}$ & $0,39 \mathrm{a}$ \\
300 & $422,00^{\mathrm{b}}$ & $233,67^{\mathrm{b}}$ & $0,38 \mathrm{a}$ \\
400 & $388,17^{\mathrm{a}}$ & $232,12^{\mathrm{b}}$ & $0,38 \mathrm{a}$ \\
\hline
\end{tabular}


Keterangan: Angka yang diikuti huruf sama pada baris menunjukkan tidak beda nyata berdasarkan uji DMRT taraf $5 \%$

\section{Hasil per hektar ${ }^{-1}$}

Hasil per hektar untuk mengetahui tingkat produksi suatu tanaman. Perlakuan varietas meningkatkan panen per hektar ${ }^{-1}$ (Gambar 3). Dosis pupuk NPK tidak meningkatkan hasil panen per hektar ${ }^{-1}$ (Gambar 4).

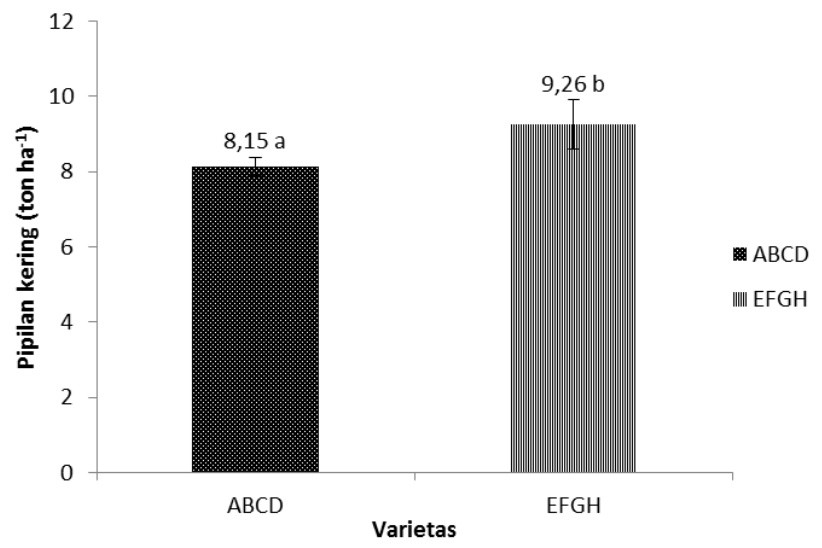

Gambar 3 Hasil pipilan kering pada dua varietas

Gambar 3 menunjukkan bahwa, varietas meningkatkan hasil per hektar. Hasil panen pipilan kering EFGH lebih tinggi mencapai 9,26 ton $\mathrm{ha}^{-1}$ (Gambar 3), sedangkan ABCD mencapai 8,15 ton ha ${ }^{-1}$ (Gambar 3), selisih antara kedua varietas variabel ini adalah 1,11 ton ha ${ }^{-1}$. Menurut deskripsi biji dari Advanta Seed Indonesia (2014), varietas ABCD memiliki ratarata hasil 8,7 ton ha $^{-1}$. Penurunan hasil dapat terjadi apabila terjadi kekurangan air saat fase pembungaan, bunga jantan dan betina muncul, serta saat terjadi proses penyerbukan. Pernyataan Aqil (2007) bahwa, dampak dari hal tersebut yaitu terhambatnya proses pengisian biji karena bunga betina atau tongkol mengering sehingga jumlah biji dalam tongkol berkurang. Hasil pipilan kering pada dosis pupuk NPK disajikan dalam Gambar 4.

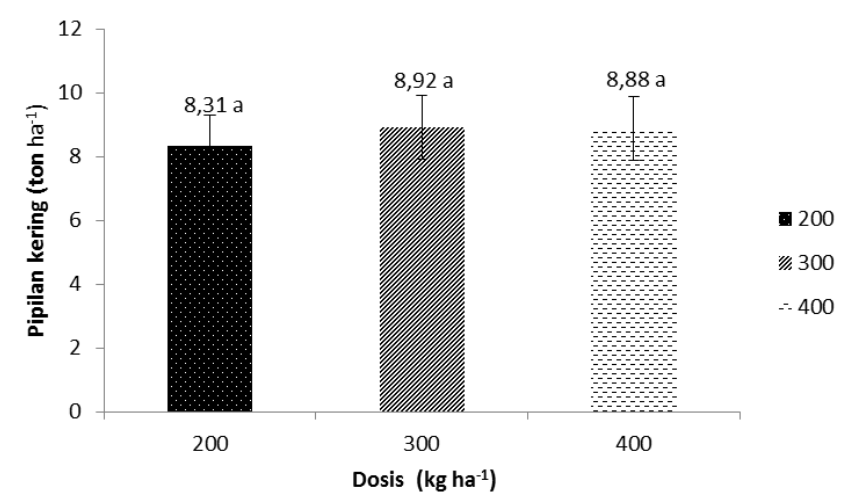

Gambar 4 Hasil pipilan kering pada dosis pupuk NPK

Dosis pupuk NPK gambar 4 menunjukkan bahwa, tidak meningkatkan hasil per hektar. Hasil tertinggi panen pipilan kering pada dosis pupuk NPK $300 \mathrm{~kg} \mathrm{ha}^{-1}$ mencapai 8,92 ton $\mathrm{ha}^{-1}$. Dosis $400 \mathrm{~kg} \mathrm{ha}^{-1}$ mencapai 8,88 ton $\mathrm{ha}^{-1}$, sedangkan $200 \mathrm{~kg} \mathrm{ha}^{-1}$ mencapai 8,31 ton ha $^{-1}$. Hal ini berbeda dengan pernyataan menurut Asghar et al (2010) bahwa, hasil jagung meningkat dengan penggunaan pupuk NPK. Menurut Taufik et al (2004), ketersediaan unsur hara berkaitan dengan proses pengisian biji. Unsur hara yang diserap akan diakumulasikan ke daun menjadi protein yang membentuk biji. Akumulasi bahan hasil metabolisme pada pembentukan biji akan meningkat, sehingga biji yang terbentuk memiliki ukuran dan berat yang maksimal, hal ini terjadi apabila terpenuhinya kebutuhan unsur hara yang menyebabkan metabolisme berjalan secara optimal.

\section{KESIMPULAN}

1. Jagung hibrida varietas (ABCD dan EFGH) respon terhadap pemupukan NPK yang optimum dalam hasil adalah EFGH $\left(9,26\right.$ ton $\left.\mathrm{ha}^{-1}\right)$.

2. Dosis NPK $300 \mathrm{~kg} \mathrm{ha}^{-1}$ optimum untuk pertumbuhan dan hasil jagung hibrida $\left(8,92\right.$ ton $\left.\mathrm{ha}^{-1}\right)$.

3. Varietas ABCD dan EFGH optimum pada dosis NPK $300 \mathrm{~kg} \mathrm{ha}^{-1}$ dalam meningkatkan potensi hasil jagung hibrida.

\section{SARAN}

Berdasarkan hasil penelitian dapat diberikan saran bahwa:

1. Varietas EFGH memiliki potensi hasil yang tinggi dibandingkan ABCD sehingga direkomendasikan untuk digunakan.

2. Dosis NPK $300 \mathrm{~kg} \mathrm{ha} \mathrm{ha}^{-1}$ dapat meningkatkan pertumbuhan dan hasil jagung hibrida sehingga direkomendasikan untuk digunakan.

\section{DAFTAR PUSTAKA}

[BPS] Badan Pusat Statistik. 2010. Indonesia dalam angka 2010. Jakarta: Badan Pusat Statistik Republik Indonesia.

Ademiluyi BO, Fabiyi EP. 2015. Response of hybrid maize (Zea mays) to organic and inorganic fertilizers in soils of South-West and North-Central Nigeria. Int J Plant Soil Sci 7(2): 121-127.

Adger, Neil W, Nigel W, Arnella, Emma LT. 2005. Successful adaptation to climate change across scales. URL:http://www.elsevier.corn. J Global Env Change 15:77-86.

Aqil M, Firmansyah IU, Akil M. 2007. Pengelolaan air tanaman jagung. URL:http://balitsereal.litbang.deptan.go.id. Maros: Balai Tanaman Serealia.

Asghar A, Ali A, Syed WH, Asif MT, Khaliq, Abid AA. 2010. Growth and yield of maize cultivars affected by NPK application in different proportion. Pakistan J Sci 62(4): 211-216.

Banzinger MS, Mugo, Edmeades GO. 2000. Breeding for drought tolerance in tropical maizeconvensional approach and challenges to molecular approaches. 
Gardner FP, Pearce B. 1991. Fisiologi tanaman budidaya. Jakarta: Universitas Indonesia Press.

Goldsworthy PR, Fisher NM. 1992. Fisiologi tanaman budidaya tropik. Yogyakarta: Gadjah Mada Universitas Press.

Haris K, Askari K. 2008. Pertumbuhan dan produksi berbagai varietas tanaman jagung pada dua dosis pupuk urea. J Agri 4(1).

lqbal M, Chauhan HOI. 2003. Relationship between different growth and yield parameters in maize under varying levels of phosphorus. J Biol Sci 3(10): 921-925.

Juandi T, Selvie T, Marjam MT. 2016. Pertumbuhan dan produksi jagung pulut lokal (Zea mays ceratina kulesh) pada beberapa dosis pupuk NPK. Manado: Universitas Sam Ratulangi.

Kasno A, Tia R. 2013. Serapan hara dan peningkatan produktivitas jagung dengan aplikasi pupuk NPK majemuk. Balai Penelitian Tanah Bogor. Penelitian Pertanian Tanaman Pangan 32(3).

Khairiyah, Siti K, Muhammad I, Sariyu E, Norlian, Mahdiannoor. 2017. Pertumbuhan dan hasil tiga varietas jagung manis (Zea mays saccharata sturt) terhadap berbagai dosis pupuk organik hayati pada lahan rawa lebak 42(3): 230-240.

Mahmood MT, Maqsood M, Awan TH, Sarwar R, Hussain MI. 2001. Effect of different levels or $\mathrm{N}$ and intra row spacing on yiled and yield components of maize.J Agric Sci 38: 48-49.

Maqsood MA, Abid MA, Iqbal, Hussain MI. 2001. Effect of variable rate of $\mathrm{N}$ and $\mathrm{P}$ on growth and yield of maize (golden). J Biol Sci 1: 19-20.

Mulyani SM. 2008. Pupuk dan cara pemupukan. Jakarta: PT Rineka Cipta.

Noviana I, Ishaq I. 2011. Karakter hasil galur dan varietas jagung pada MK II di Jawa Barat. Prosiding Seminar Nasional Pengkajian dan Diseminasi Inovasi Pertanian Mendukung Program Strategis Kementrian Pertanian. Cisarua 9-11.

Rahni NM. 2012. Efek fitohormon PGPR terhadap pertumbuhan tanaman jagung (Zea mays). J Agribisnis Pengembangan Wilayah 3(2): 27-35.

Ramanta AE. 2008. Pengaruh efektivitas pupuk hayati petrobio pada pertumbuhan dan hasil tanaman jagung hibrida (Zea mays) BISI-16. Skripsi. Universitas Brawijaya Malang.
Sathish AG, Gowda VH, Chandrappa, Kusagur N. 2011. Long term effect of integrated and inorganic fertilizers on productivity, soil fertility and uptake of nutrients in rice and maize cropping system. I J S N 2(1): 84-88.

Sharer MS, Ayub M, Nadeem MA, Ahmad N. 2003 Effect of different rates of $\mathrm{N}$ and $\mathrm{P}$ on growth and grain yield of maize. Asian Plant Sci 2(3): 347-349.

Stephen O, Animasaun DA, Bello AA, Agboola OO. 2014. Effect of NPK and poultry manure on growth, yield and proximate composition of three Amaranths. J Botany. URL:http://dx.doi.org.

Suarni, Yasin M. 2011. Jagung sebagai sumber pangan fungsional. J Iptek Tanaman Pangan 6(1): 41-56.

Subekti NA, Syafiruddin, Efendi R, Sunarti S. 2007. Morfologi tanaman dan fase pertumbuhan jagung Sulawesi Selatan. Balai Penelitian Tanaman Serealia Sulawesi Selatan. URL: http://balitsereallitbang.deptan.co.id.

Suratmini P. 2009. Kombinasi pemupukan urea dan pupuk organic pada jagung manis di lahan kering. Penelitian Tanaman Pangan 28(2).

Syarifuddin, Muhammad A, Suwarti. 2012. Pengembangan jagung toleran naungan dan $\mathrm{N}$ rendah pada lahan diantara tanaman perkebunan dengan tingkat produktivitas minimal 7 ton $\mathrm{ha}^{-1}$.

Taufiq A, Kuntyastuti H, Manshuri AG. 2004. Pemupukan dan ameliorasi lahan kering untuk peningkatan produktivitas kedelai. Prosiding Lokakarya Pengembangan Kedelai Melalui Pendekatan Pengelolaan Tanaman Terpadu di Lahan Kering. Balai Penelitian Aneka Kacang dan Umbi.

Tuberkih E, Sipahutar IA. 2008. Pengaruh pupuk NPK majemuk (16-16-15) terhadap pertumbuhan dan hasil jagung (Zea mays) di tanah Inceptisols. Balai Penelitian Tanah Bogor 10-11.

Yulisma. 2011. Pertumbuhan dan hasil beberapa varietas jagung pada berbagai jarak tanam. Penelitian Pertanian Tanaman Pangan 30(3): 196203. 